\title{
Peningkatan Hasil Belajar IPA Siswa Melalui Penerapan Model Pembelajaran Kooperatif Tipe Group Investigation di Sekolah Dasar
}

\author{
Yonarlianto Tembang1*, Diah Harmawati², Julinda Priskila Rahajaan ${ }^{3}$ \\ 1,3 Jurusan Pendidikan Guru Sekolah Dasar, Universitas Musamus Merauke \\ 2 Jurusan Pendidikan Guru Pendidikan Anak Usia Dini, Universitas Musamus Merauke
}

\author{
A R T I C L E I N F O \\ Article history: \\ Received 10 February \\ 2019 \\ Received in revised form \\ 09 March 2019 \\ Accepted 15 April 2019 \\ Available online 25 May \\ 2019 \\ Kata Kunci: \\ Hasil Belajar, IPA, Group \\ Investigation \\ Keywords: \\ Social Science, Problem \\ Based Learning, Rolle \\ Pyaing, the motivation, the \\ results of the study.
}

\begin{abstract}
A B S T R A K
Tujuan penelitian ini untuk meningkatkan hasil belajar siswa kelas $\mathrm{V}$ melalui penerapan model pembelajaran kooperatif tipe group investigation pada mata pelajaran IPA di SDN Wasur Merauke. Penelitian yang gunakan adalah penelitian tindakan kelas (PTK) dengan jenis penelitian kolaborasi dan dilaksanakan sebanyak dua siklus. Setiap siklusnya terdiri dari 4 tahapan yaitu perencanaan, pelaksanaan, observasi, dan refleksi dan dilaksankan dalam 3 pertemuan. Subjek dalam penelitian terdiri dari 26 siswa yang terdiri dari 15 siswa laki-laki dan 11 siswa perempuan. Teknik analisis data yang digunakan yaitu analisis data lembar observasi yang digunakan untuk mengetahui keterlaksanaan model pembelajaran dan hasil belajar siswa dalam pembelajaran IPA. Berdasarkan hasil penelitian ini, diperoleh hasil keterlaksanaan model pembelajaran mengalami peningkatan di setiap siklus I sebesar $66,0 \%$ dalam kategori cukup menjadi $72,5 \%$ pada siklus II dalam kategori baik. . Sedangkan persentase ketuntasan hasil belajar siswa pada siklus I sebesar $64,4 \%$ dan pada siklus II persentase
\end{abstract} kentuntasan belajar siswa meningkat sebesar $80.7 \%$. Hal ini dapat disimpulkan bahwa dengan menerapkan model pembelajaran kooperatif tipe group investigation dapat meningkatkan hasil belajar IPA siswa kelas V SDN Wasur Merauke.

\begin{abstract}
A B S T R A C T
The purpose of this study was to improve the learning outcomes of fifth-grade students through the application of Cooperative learning models of type group investigation to science subjects at Wasur Merauke Elementary School. The research used was classroom action research (PTK) with a type of collaborative research and carried out in two cycles. Each cycle consists of 4 stages, namely planning, implementation, observation, and reflection and carried out in 3 meetings. The subjects in the study consisted of 26 students consisting of 15 male students and 11 female students. The data analysis technique used is the data analysis of the observation sheet used to determine the feasibility of the learning model and student learning outcomes in science learning. Based on the results of this study, the results of the implementation of the learning model increased in each cycle I by $66.0 \%$ in the sufficient category to be $72.5 \%$ in the second cycle in the good category. While the percentage of completeness of student learning outcomes in the first cycle amounted to $64.4 \%$ and in the second cycle the percentage of student learning completeness increased by $80.7 \%$. It can be concluded that by applying the cooperative learning model type group investigation can improve science learning outcomes of fifth-grade students of Wasur Merauke Elementary School .
\end{abstract}

\section{Pendahuluan}

Pendidikan dasar merupakan pondasi awal bagi siswa untuk membuka wawasannya dan memegang peranan penting untuk meningkatkan kualitas sumber daya manusia di masa yang akan

Copyright ( Universitas Pendidikan Ganesha. All rights reserved. 
datang. Terdapat beberapa bidang dalam pelajaran yang harus dikuasi oleh siswa sekolah dasar dalam mengembangkan kemampuan kognitifnya untuk mencapai tujuan pendidikan yang telah ditetapkan. Salah satunya adalah Ilmu Pengetahuan Alam (IPA). Mata pelajaran IPA tergolong dalam kelompok mata pelajaran ilmu pengetahuan dan teknologi pada jenjang SD/MI/SDLB yang dimaksudkan untuk mengenal, menyikapi, dan mengapresiasi ilmu pengetahuan dan teknologi, serta menanamkan kebiasaan berpikir dan berperilaku ilmiah yang kritis, kreatif, dan mandiri (Permendiknas No. 22 Tahun 2006:3). Trianto (2014:136) mengemukakan IPA adalah pengetahuan terstruktur, sistematis telah teruji sehingga bersifat umum (universal) namun dinamis membentuk pengetahuan baru dan secara umum terbatas pada gejalagejala alam. IPA membahas tentang gejala-gejala alam yang disusun secara sistematis sesuai fakta melalui observasi, eksperimentasi, penyimpulan dan penyusunan teori oleh manusia.

Pelajaran IPA ditingkat sekolah dasar (SD) mengajarkan tentang konsep-konsep dasar dan memperkenalkan kepada siswa tentang alam sekitar. BSNP (2006.161 dalam Wisudawati, A. \& Anggaryani, 2014:10), mengemukakan bahwa pelajaran IPA di tingkat SD dianggap sebagai pembelajaran yang mengenai konsep pendidikan yang bersentuhan dengan aspek alam beserta kejadian-kejadian yang ada di lingkungan sekitar. Proses pembelajaran IPA menekankan pada pemberian pengalaman langsung yang menitik beratkan pada suatu proses, hal ini terjadi ketika belajar IPA mampu meningkatkan proses berfikir siswa melalui tindakan yang dilakukan siswa untuk mencapai tujuan yang diharapkan (Wisudawati, A. \& Anggaryani, 2014:10). Oleh karena itu proses pembelajaran IPA di SD tidak hanya untuk dapat memahami kumpulan fakta-fakta, tetapi juga mengajarkan cara berfikir dan bekerja ilmiah agar siswa dapat memecahkan suatu masalah yang dihadapi. Dalam pelajaran IPA di SD guru dituntut untuk menguasai bahan pembelajaran dan hendaknya dapat merancang media-media serta menerapkan model-model pembelajaran yang dapat melibatkan siswa aktif dalam proses pembelajaran. Agar proses pembelajaran IPA di kelas lebih bermakna dan tujuan pembelajaran yang diharapkan dapat tercapai secara optimal.

Muatan yang terdapat dalam KTSP meliputi berbagai pelajaran yang salah satunya adalah pembelajaran IPA. Pembelajaran IPA di SD selalu menekankan pada pengalaman secara langsung sesuai dengan karakteristik dan kemampuan siswa. Kemampuan yang berbeda-beda yang dimiliki oleh siswa dalam satu kelas membuat pembelajaran IPA sangat menarik untuk dipelajari, karena siswa bukan hanya dituntun dari segi pengetahuan namun dari segi keterampilan siswa. Keterampilan yang dimiliki siswa menekankan kepada fakta dan pendekatan konsep, yang didasarkan pada langkah-langkah kegiatan dan menguji sesuatu hal yang biasa dilakukan oleh orang lain untuk membuktikan suatu teori sesuai dengan prosedurnya.

Penguasaan konsep IPA juga dipengaruhi oleh gaya mengajar guru dikelas, hal ini dibuktikan berdasarkan hasil observasi yang dilakukan dalam proses pembelajaran IPA hasil belajar siswa terlihat masih rendah dikarenakan beberapa hal, diantaranya; 1) proses pelaksanaan pembelajaran yang dilakukan guru masih sering menggunakan metode ceramah tanpa memberikan umpan balik kepada siswa sehingga siswa terlihat bosan dan tidak semangat untuk belajar lagi; 2) terlihat siswa pada saat proses pembelajaran bermain sendiiri dan mengobrol dengan teman sebangkunya dan beberapa siswa tidak fokus dalam memperhatikan pelajaran sehingga guru bertanya tentang pelajaran siswa tidak mampu untuk menjawab pertanyaan dari guru; 3) berdasarkan hasil tes yang dilakukan pada mata pelajaran IPA yang dilakukan pada prasiklus dari 26 siswa kelas VB SD Negeri Wasur 2 Merauke hanya 12 siswa yang tuntas dengan nilai KKM 65 dengan prsentase 46,2\%. Sedangkan siswa yang belum tuntas ada 14 siswa dengan presentase 53,8\% sehingga diperlukan suatu model pembelajaran yang dapat menumbuhkan semangat siswa dalam proses pembelajaran untuk meningkatkan hasil belajarnya. (Winkel, 2009) mengemukakan bahwa untuk mengetahui keberhasilan proses belajar mengajar seseorang yakni pada hasil belajar seseorang tersebut diwujudkan dalam bentuk angka sehingga dapat mengetahui tingkat pemahaman seseorang tersebut setelah diberikan perlakuan. Dalam proses belajar mengajar guru harus memiliki strategi yang dapat membuat siswa untuk bekerja secara efektif dan efesien, tepat pada tujuan yang telah ditetapkan. Salah satu langkah untuk memiliki model atau strategi itu adalah harus menguasai teknik-teknik penyajian materi, atau biasa disebut dengan model-model pembelajaran (Wiratana, 2013)

Model pembelajaran kooperatif merupakan bentuk pembelajaran yang menenkan pada kerjasama didalam kelompok-kelompok kecil secara kolaboratif. (Lie, 2008), mengemukkan bahwa untuk mencapai suatu hasil yang maksimal dalam model pembelajaran kooperatif ada lima unsur yang harus diperhatikan yaitu; 1) saling ketergantungan; 2) tanggung jawab perseorangan; 3) tatap muka; 4) komunikasi antar anggota dan 5) Evaluasi proses kelompok. Salah satu model pembelajaran yang sesuai dengan tuntutan tersebut adalah model pembelajaran kooperatif tipe group investigation. Model pembelajran GI merupakan pembelajaran berbasis kelompok yang memberikan peluang kepada siswa untuk berdiskusi, berfikir kritis, dan dapat bertanggung jawab dalam pembelajaran tersebut (Artini, P. M. \& Husain, 
2016:45-52). Model ini juga mampu menumbuhkan kehangatan hubungan antara pribadi dalam diri siswa, rasa hormat, terhadap aturan dan kebijakan, kepercayaan, kemandirian dalam belajar sendiri serta hormat terhadap harkat dan martabat orang lain. (Aunnurahman, 2012), mengemukkan bahwa model pembelajaran yang secara langsung dan efisien mampu mengajarkan pengetahuan akademik sebagai suatu proses awal sosial bagi siswa.

Berdasarkan masalah yang telah didapatkan melalui tes awal pada prasiklus hasil belajar siswa masih sangat rendah jauh dari nilai KKM yang telah ditetapkan, maka harus dliakukan suatu perbaikan dengan cara berkolaborasi bersama guru kelas melalui penelitian tindakan kelas serta menerapkan model pembelajaran koopertaif tipe group investigation (GI). Penerapan model pembelajaran kooperatif tipe GI diharapkan dapat meningkatkan hasil belajar siswa pada materi sifat bahan dan struktur penyusunnya. Tujuan penelitian ini adalah untuk meningkatkan hasil belajar IPA siswa kelas VB SD Negeri Wasur Merauke dengan penerapan model pembelajaran kooperatif tipe GI.

\section{Metode}

Penelitian ini merupakan penelitian tindakan kelas (PTK), jenis kolaborasi yakni dimana peneliti bekerja sama dengan guru kelas dengan model bersiklus. Setiap silklus memiliki empat tahap yaitu; 1) perencanaan; 2) pelaksanaan; 3) observasi; dan 4) refleksi. Penelitian ini dilaksanakan di SD Negeri Wasur yang bertempat di kelurahan rimba jaya dengan alamat Trans Papua Merauke. Subjek dalam penelitian ini adalah siswa kelas VB SD Negeri Wasur Merauke yang berjumlah 26 siswa. Data dalam penelitian ini dikumpulkan dengan menggunakan lembar keterlaksanaan model IG berupa lembar observasi dan lembar tes hasil belajar siswa yang diberikan pada akhir siklus, tujuannya adalah mengetahui pemahaman hasil belajar siswa pada setiap pertemuan dari segi kognitifnya.

Data hasil belajar siswa dan lembar observasi dihitung dengan membandingkan jumlah skor yang diperoleh siswa dengan jumlah skor maksimal kemudian di kalikan 100\%. Persentase yang diperoleh pada lembar observasi digolongkan dalam masing-masing kategori yaitu, kurang, cukup, baik, dan sangat baik. Selajutnya dapat dilihat pada tabel 1 .

Tabel 1. Kategori Tingkat Keberhasilan siswa

\begin{tabular}{l|l}
\hline Tingkat Keberhasilan $(\%)$ & Kategori \\
\hline $81-100$ & Sangat Baik \\
$66-80$ & Baik \\
$56-65$ & Cukup \\
$0-55$ & Kurang \\
\hline
\end{tabular}

Analisis ketuntasan belajar siswa secara klasikal pada ranah kognitif dihitung dengan membandingkan jumlah siswa yag tuntas dengan jumlah keseluruhan siswa kemudian dikalikan $100 \%$. Menghitung kentuntasan belajar siswa secara klasikal dengan menggunakan rumus sebagai berikut.

$$
\text { Ketuntasan Belajar Siswa Secara Klasikal } \frac{\text { Jumlah siswa yang tuntas }}{\text { Jumlah keseluruhan siswa }} \text { X } 100
$$

(Purwanto, 2013:132)

Penelitian ini dikatakan berhasil apabila minimal $\geq 75 \%$ jumlah siswa yang mampu mencapai standar nilai KKM 65 dikatakan tuntas. Sedangkan $<75 \%$ jumlah siswa yang belum mencapai standar nilai KKM 65 dikatakan belum tuntas, sehingga perlu dilanjutkan pada siklus selanjutnya.

\section{Hasil dan Pembahasan}

\section{Siklus I}

Proses model pembelajaran kooperatif tipe GI dilaksanakan selama dua siklus, setiap siklusnya terdiri dari tiga kali pertemuan, pertemuan yang ketiga dilaksanakan tes akhir siklus untuk mengetahui sejauh mana materi yang telah dipelajari dan dipahami oleh siswa. Materi pertemuan satu dan dua yang diajarkan adalah materi bahan dan sifat penyusun benda sedangkan pada siklus kedua pertemuan pertama sampai pada pertemuan kedua materi yang diajarkan yaitu hubungan jenis bahan dan teknik pembuatannya. Pertemuan ketiga dilaksanakan tes siklus kedua sama seperti pada siklus yang 
sebelumnya. Kegiatan observasi dilakukan bersamaan dengan pelaksanaan proses pembelajaran dalam kelas yang terdiri dari 12 aspek dengan skor yang tertinggi untuk setiap item adalah empat dan skor terendah untuk setiap item adalah satu, hasil lembar observasi keterlaksanan proses pembelajaran dengan penerapan model GI dapat dilihat pada Tabel 2.

Tabel 2. Presentase Keterlaksanaan Model GI pada siklus I

\begin{tabular}{|c|c|c|c|c|}
\hline No & Pertemuan & Skor & $\begin{array}{l}\text { Persentase Keterlaksanaan } \\
\text { Keterlaksanaan Model GI }\end{array}$ & Kategori \\
\hline 1 & Pertama & 30 & $62,2 \%$ & Cukup \\
\hline 2 & Kedua & 34 & $70,0 \%$ & Baik \\
\hline \multicolumn{3}{|c|}{ Rata-rata Persentase } & $66,0 \%$ & Baik \\
\hline
\end{tabular}

Berdasarkan hasil pengamatan yang di peroleh pada siklus satu keterlaksanaan model GI pada setiap pertemuan mengalami peningkatan, pertemuan pertama sebesar $62,2 \%$ atau dalam kategori cukup dan pada pertemuan kedua meningkatkan sebesar $70,0 \%$ dengan kategori baik. Rata-rata persentase keterlaksanaan model GI pada siklus pertama sebesar 66,0\% dengan kataegori baik. Permasalaha yang didapatkan pada pertemuan pertama dikarena guru belum terbiasa menerapkan model GI pada proses pembelajaran, dan pada pertemuan kedua guru mulai terbiasa dengan model GI serta memperbaik kesalahan pada pertemuan pertama dengan arahan observer. Hasil tes siswa pada siklus pertama juga mengalami peningkatan banyak siswa yang lebih tuntas dibandingkan siswa yang tidak tuntas tetapi hal ini belum mencapai indikator keberhasilan. Hasil belajar siswa pada siklus pertama dapat dilihat pada Tabel 3.

Tabel 3. Kentuntasan Hasil Belajar IPA pada Siklus I.

\begin{tabular}{llll}
\hline Capaian Nilai & Kategori & Frekuensi & Persentase \\
\hline $0-64$ & Belum Tuntas & 9 & $34,6 \%$ \\
$65-100$ & Tuntas & 17 & $65,4 \%$ \\
\hline
\end{tabular}

Hasil analisis yang diperoleh menunjukkan masih perlu perbaikan pada siklus berikutnya karena ketuntasan belajar secara klasikal belum mencapai kriteria yang telah ditentukan yaitu sebesar $75 \%$ dari jumlah keseluruahan siswa di dalam kelas yang telah mencapai nilai $\geq 65 \mathrm{KKM}$. Kegiatan refleksi yang dilakukan pada siklus satu untuk memperbaiki permasalahan yang terjadi diantarannya; 1) penerapan model GI dalam pembelajaran IPA telah terlaksanaan cukup baik jumlah anggota dalam setiap kelompol yang berjumlah 5-6 orang siswa memicu siswa untuk ramai sendiri, guru mengurangai jumlah anggota dalam tiap kelompok menjadi 3 orang; 2) guru belum melaksanakan alokasi waktu KBM dengan tepat; 3)ada beberapa siswa yang kurang pasif dan tidak mau berpendapat dalam kelompokknya karena kurang percaya diri guru memberikan masukan kepada kelompok agar tetap kompak agar suasana lebih mengasikkan.

\section{Siklus II}

Penelitian pada Siklus II dilaksanakan pada tanggal 06 - 13 Agustus dilakukan berdasarkan hasil refleksi siklus I, yaitu hasil belajar siswa secara klasikal belum mencapai indikator yang telah ditentukan dan observasi keterlasanaan model GI masih di bawa kategori. Berdasarkan hasil observasi pada Siklus II terhadap keterlaksanaan model GI telah menunjukkan tahap kesempurnaan disetiap pertemuannya hal ini dapat diketahui berdasarkan hasil persentase analisis lembar keterlakasanaan pada Tabel 4

Tabel 4. Presentase Keterlaksanaan Model GI pada Siklus II

\begin{tabular}{lllcl}
\hline \multirow{2}{*}{ No } & Pertemuan & \multirow{2}{*}{ Skor } & \multicolumn{2}{c}{ Persentase Keterlaksanaan } \\
& Pertama & 34 & $70,0 \%$ & Kategori \\
\hline 1 & Kedua & 36 & $75,5 \%$ & Baik \\
2 & Rata-rata Persentase & & $72,5 \%$ & Baik \\
& & & Baik \\
\hline
\end{tabular}

Hasil pengamatan yang dilakukan observer pada Siklus II menunjukkan bahwa proses pembelajaran model GI pada mata pelajaran IPA telah terlaksanaa dengan baik disetiap aspeknya, kegiatan dibuktikan pada masing-masing pertemuan sudah mencapai indikator yang telah ditetapkan dan 
dalam kategori baik. Kegiatan refleksi yang dilakukan pada akhir siklus I sebelum masuk ke Siklus II sangat membantu dalam penelitian ini. Kegiatan perencanaan awal dilakukan dengan menekankan pada permasalahan yang menjadi dasar sehingga keterlaksanaan model GI dapat mencapai tujuan pembelajaran di setiap aspek. Hasil belajar siswa pun mengalamai peningkatkan pada Siklus II hal ini dapat dilihat berdasarkan analisis data yang dilakukan pada Siklus II pada Tabel 5 berikut:

Tabel 5. Ketuntasan Hasil Belajar IPA pada Siklus II

\begin{tabular}{llll}
\hline Capaian Nilai & Kategori & Frekuensi & Persentase \\
\hline $0-64$ & Belum Tuntas & 5 & $19,3 \%$ \\
$65-100$ & Tuntas & 21 & $80,7 \%$ \\
\hline
\end{tabular}

Berdasarkan Tabel 5 di atas terlihat bahwa ketuntasan belajar siswa pada Siklus II telah mencapai indikator yang telah ditentukan yaitu $\geq 75 \%$ jumlah siswa yang telah mencapai nilai KKM 65 . Dan hal ini mengalami peningkatan jumlah siswa yaitu jumlah siswa yang tuntas sebesar 21 siswa dengan persentase sebesar $80,7 \%$ sedangkan yang tidak tuntas sebesar 5 siswa dengan persentase 19,3\%. Peningkatan ketuntasan hasil belajar IPA pada Siklus II ini di pengaruhi karena adanya perubahan gaya belajar yang dilakukan siswa pada pertemuan pertama dan kedua hasil dari refleksi yang dilakukan pada akhir siklus 1. Hal ini membuktikan bahwa penerapan model pembelajaran kooperatif tipe GI dapat meningkatkan hasil belajar siswa pada matapelajaran IPA di SD Negeri II Wasur Merauke.

Hasil belajar siswa dalam penerapan model pembelajaran kooperatif tipe GI pada siswa kelas V SD Negeri II Wasur Merauke materi ajar bahan penyusun benda dan sifatnya mengalami peningkatan disetiap siklusnya. Hasil belajar tersebut di pengaruhi karena adanya perubahan gaya belajar dari siklus I ke Siklus II sehingga mempengaruhi faktor internal pada diri siswa itu sendiri, faktor internal yang berpengaruh terhadap peningkatan hasil belajar siswa yaitu rasa senang untuk mengikuti pembelajaran dengan penerapan model kooperatif tipe GI. Faktor internal yang mempengaruhi tersebut dibuktikan dengan lembar pengamatan yang diberikan setiap pertemuan untuk mengamati proses keterlaksanaan model GI terhadap kemampuan siswa pada materi bahan penyusun benda dan sifatnya. (Sadirman, 2005:96), mengemukkan Aktivitas belajar merupakan serangkaian kegiatan fisik atau jasmani maupun mental atau rohani yang saling berkaitan sehingga terciptanya suatu proses belajar yang optimal. Persentase keterlaksanaan model pembelajaran GI mengalami peningkatan dari siklus I sebesar $66,00 \%$ menjadi $72,50 \%$ pada Siklus II peningkatan persentase keterlaksanaan model GI dari siklus I ke Siklus II sebesar 6,50\%. Persentase peningkatan keterlaksanaan pembelajaran dapat dilihat pada gambar 1.

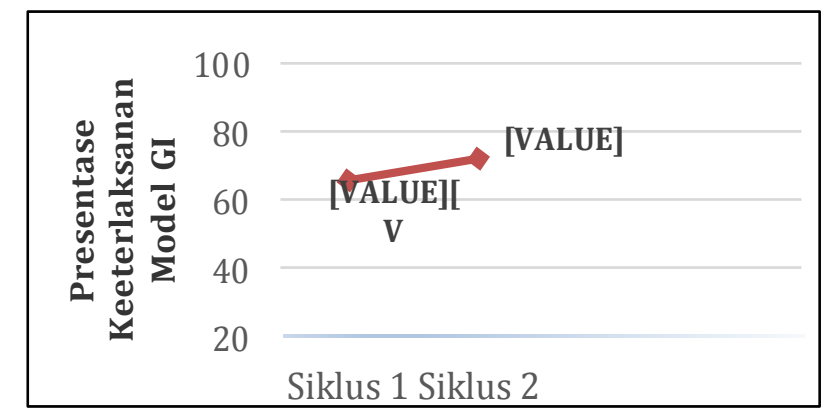

Gambar 1. Diagram persentase keterlaksanaan model pembelajaran GI pada siklus I dan Siklus II

Berdasarkan gambar 1 terlihat bahwa keterlaksanaan model pembelajaran GI yang telah dilakukan oleh guru pada siklus 1 memperoleh persentase keterlaksanaan sebesar 66,0\%. Namun keterlaksanaan tersebut belum mencapai kategori yang telah ditentukan secara optimal karena masih terdapat kekurangan yakni pada saaat pertemuan pertama, guru belum melaksanakan alokasi waktu KBM dengan baik, setelah adanya perbaikan yang dilakukan pada siklus ke 2 keterlaksanaan model GI mengalami peningkatan menjadi $72,5 \%$. Guru telah melaksanakan semua tahapan yang merupakan sintaks dari model pembelajaran GI dengan baik. Sebagaian besar aspek pada lembar pengamatan keterlaksanaan model GI mencapai skor maksimal. Hal ini menunjukkan keberhasilan guru dalam menerapkan model pembelajaran GI terlaksana dengan baik.

Salah satu faktor yang mempengaruhi hasil belajar siswa selain faktor internal pada diri siswa faktor lain yang mempengaruhi yaitu faktor eksternal yang mempengaruhi peningkatan hasil belajar siswa adalah model pembelajaran kooperatif tipe GI yang digunakan guru dalam setiap pertemuan. Hasil 
belajar siswa mengalami peningkatan dengan penerapan model GI jika dibandingkan dengan proses pembelajaran sebelumnya. Persentase ketuntasan hasil belajar siswa dapat dilihat pada gambar 2 .

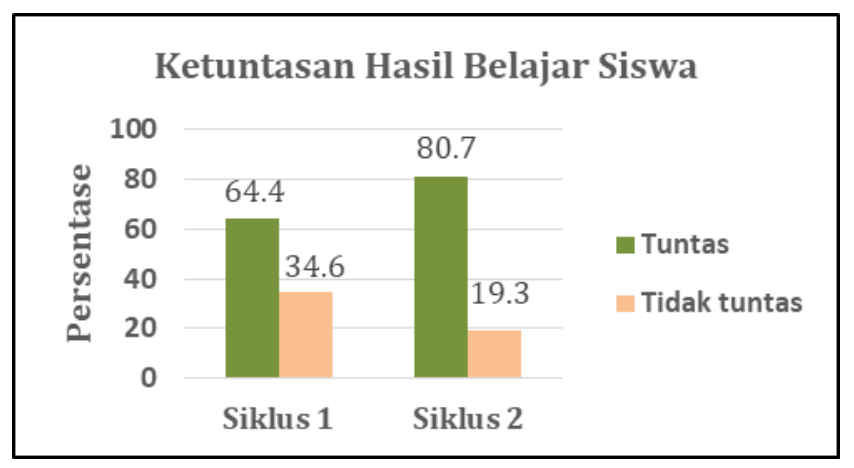

Gambar 2. Diagram persentase ketuntasan hasil belajar siswa

Berdasarkan gambar 2 terlihat peningkatan persentase hasil belajar siswa dari siklus 1 ke Siklus II sudah mencapai indikator yang telah ditetapkan. Pada siklus 1 peningkatan hasil belajar siswa sebesar $64,4 \%$ atau 17 siswa yang telah dikatakan tuntas belajar sedangkan yang tidak tuntas sebesar $34,6 \%$ atau 9 siswa. hal ini disebabkan karena ada beberapa kelompok yang masih pasif dalam menyampaikan pendapatnya, guru juga belum melakukan KBM sesuai dengan waktu yang telah ditetapkan. Setelah melakukan perbaikan pada Siklus II, hasil belajar siswa mengalami peningkatan. Ketuntasan hasil belajar siswa pada Siklus II sebesar $80.7 \%$ atau 21 siswa telah tuntas hasil belajar sedangkan siswa yang tidak tuntas sebesar 19,3\% atau 5 siswa. Hal ini menunjukkan bahwa ketuntasan hasil belajar siswa secara klasikal telah mencapai indikator keberhasilan yang telah ditentukan sebesar 75\%. Sanjaya (2016:107) menyatakan setiap individu dapat mengembangkan pengetahuan berdasarkan struktur kognitif yang dimiliki pada diri sendiri, guru mengarahkan pada usaha membimbing dan menciptakan lingkungan belajar yang dapat mendorong terhadap pengembangan pengetahuan siswa tersebut.

Penelitian lainnya yang dilakukan oleh (Muliyantini \& Desak, 2017) yang berjudul "Penerapan Model Pembelajaran Group Investigation (GI) untuk meningkatkan hasil belajar IPA kelas V berdasakan penelitian tersebut menunjukkan bahwa nilai hasil belajar IPA meningkatkan disetiap siklus, hal tersebut dibuktikan pada siklus I nilai rata-rata hasil belajar IPA 66,67\% dalam kategori sedang, perbaikan yang dilakukan pada Siklus II dapat meningkatkan hasil belajar siswa denagan nilai rata-rata 90,91\% dengan kategori sangat tinggi pengumpulan data yang digunakan dalam penelitian ini yaitu menggunakan tes evaluasi diakhir siklus. Hasil penelitian ini sesuai dengan hasil penelitian yang didapatkan oleh (Erlinawati \& Marhadi, 2014) yang menyebutkan bahwa model pembelajaran group investigation dapat meningkatkan hasil belajar IPS dan dapat meningkatkan kualitas pembelajaran siswa. Berdasarkan penelitian tersebut, penggunaan model pembelajaran kooperatif tipe group investigation dalam pembelajaran telah menunjukkan hasil yang positif. Penelitian oleh (Halimah, dkk.,2019) yang menunjukkan hasil belajar IPA siswa yang belajar dengan model pembelajaran kooperatif tipe GI berbantuan media virtual laboratory relatif lebih tinggi dibandingkan pembelajaran Direct Instruction. Penelitian oleh (Muliyantini \& Desak, 2017) menunjukkan bahwa penerapan model pembelajaran Group Investigation (GI) dapat efektif meningkatkan hasil belajar IPA, materi sifat bahan dan struktur penyusunnya pada siswa kelas V SD No. 1 Abianbase. Penelitian oleh Wardana, dkk, (2014) menunjukkan bahwa terdapat perbedaan yang signifikan hasil belajar antara kelompok siswa yang mengikuti model pembelajaran Group Investigation (GI) berbantuan asesmen proyek dengan kelompok siswa yang mengikuti model pembelajaran konvensional

Berdasarkan uraian dan penelitian terdahulu maka penelitian ini boleh dikatakan telah berhasil karena kriteria hasil yang telah ditentukan telah tercapai, dan dapat diinterpretasikan bahwa dengan penerapan model koopertatif tipe GI dapat meningkatkan hasil belajar siswa kelas V SD Negeri Wasur Merauke Tahun Ajaran 2018/2019.

\section{Simpulan dan Saran}

Berdasarkan penelitian ini model pembelajaran kooperatif tipe GI dapat meningkatkan hasil belajar IPA siswa kelas V SD Negeri Wasur Merauke Tahun Ajaran 2018/2019. Hal ini terbukti pada peningkatkan hasil belajar siswa dari siklus 1 sebesar 64,4\% dengan jumlah yang tuntas 17 siswa pada kategori baik, 
selanjutnya pada Siklus II peningkatkan hasil belajar siswa meningkatkan menjadi 80.7\% dengan jumlah yang tuntas 21 siswa berada pada kategori baik. Berdasarkan hasil penelitian yang telah didapatkan maka peneliti mengajukan saran guna meningkatkan kualitas pendidikan serta peningkatan kualitas pembelajaran IPA untuk sekolah dasar sebagai berikut: Pertama, penerapan model pembelajaran kooperatif tipe GI hendaknya diperkenalkan dan dikembangkan oleh seorang pendidik guna menciptkan suasana yang menyenangkan namun tetap fokus pada materi yang akan diajarkan. Kedua, bagi mahasiswa atau calon guru nanti hendaknya terus menerus diperkenalkan dan dilatih untuk menerapkan modelmodel pembelajaran kooperatif yang sesuai dengan karakteristik siswa di sekolah siswa, sehingga siswa tidak hanya mendengar penjelasan guru terus menerus tetapi dapat terlibat langsung dalam pembelajaran tersebut. Ketiga, penelitian yang telah dilaksanakan ini disarankan bagi peneliti selanjutnya untuk meningkatkan keterampilan berpikir kritis dan keterampilan psikomotorik siswa pada mata pelajaran IPA di sekolah dasar..

\section{Daftar Rujukan}

Artini, P. M. \& Husain, S. M. . (2016). Penerapan Model Pembelajaran Kooperatif Tipe Group Investigation untuk Meningkatkan Aktivitas dan Hasil Belaja IPA pada Siswa Kelas VI SD Inpres I Tondo. Jurnal Riset Pendidikan MIPA. Universitas Tadulako, 4(1).

Aunnurahman. (2012). Belajar dan Pembelajaran. Bandung: Alfabeta.

Erlinawati \& Marhadi. (2014). Penerapan Model Pembelajaran Kooperatif Tipe Group Investigation untuk Meningkatkan Hasil Belajar IPS Siswa Kelas IV SD Negeri 56 Pekanbaru. Primary: Jurnal Pendidikan Guru Sekolah Dasar, 3(1), 9-14.

Halimah, N. \& Ketut Suma \& Putri Sarini. (2019). Pengaruh Model Pembelajaran Kooperatif Tipe Group Investigation Berbantuan Media Virtual Laboratory Terhadap Hasil Belajar IPA Siswa. JPPSI: Jurnal Pendidikan Dan Pembelajaran Sains Indonesia, 1(1).

Lie, A. (2008). Cooperative Learning (Mempraktikan Cooperative Learning di Ruang-ruang Kelas). Jakarta: PT.Grasindo.

Muliyantini, N. P. \& Desak Putu Parmithi. (2017). Penerapan Model Pembelajaran Group Investigation (GI) untuk Meningkatkan Hasil Belajar IPA Kelas. Jurnal Ilmiah Sekolah Dasar, Universitas Pendidikan Ganesha, 1(2).

Purwanto, M. N. (2013). Prinsip-prinsip dan Teknik Evaluasi Pembelajaran. Bandung: Remaja Rosdakarya. Riduwan. (2015). Skala Pengukuran Variabel-variabel Penelitian. Bandung: Alfabeta.

Sanjaya, W. (2016). Strategi Pembelajaran Beorientasi Setandar Proses Pendidikan. Jakarta: Kencana.

Wardana, I W. \& Ni Made Setuti \& I Gde Wawan Sudatha. (2014). Pengaruh Model Pembelajaran Group Investigation Berbantuan Asesmen Proyek Terhadap Prestasi Belajar IPA Siswa Kelas V Sekolah Dasar Gugus III Tampak Siring. E-Journal Pendidikan Guru Sekolah Dasar Undiksha, 3(1).

Winkel. (2009). Psikologi Pengajaran. Jakarta: Media Abadi.

Wiratana, K. I. dkk. (2013). Pengaruh Model Pembelajaran Kooperatif tipe Investigasi Kelompok (Group Investigation) Terhadap Keterampilan Proses dan Hasil Belajar Sains Siswa SMP. Jurnal Pendidikan Dan Pembelajaran IPA Indonesia, 3(1).

Wisudawati, A \& Anggaryani, M. (2014). Penerapan Pembelajaran Fisika Bedasarkan Strategi Brain Based Learning untuk Meningkatkan Keterampilan Berpikir Kritis siswa pada Materi Elastisits Kelas XI di Sma Negeri 1 Wonoayu Sidoarjo. Jurnal Inovasi Pendidikan Fisika. Universitas Negeri Surabaya, 3(2). 